\title{
DIFFICULTIES IN THE INTERPRETATION OF URINARY IODINE EXCRETION IN PREGNANT WOMEN
}

\section{Zsuzsanna Szántó1,2, Attila Csiszér ${ }^{3}, Z^{2}$ suzsanna Croitorescư ${ }^{4}$, I.Z. Kun ${ }^{5}$}

1. University of Medicine and Pharmacy, Department of Endocrinology, Tîrgu Mureş, România; 2. Clinical Hospital Mureş County, Clinical Section of Endocrinology, Tîrgu Mureş, România; 3. Regional Center of Public Health, National Institute of Public Health Tîrgu Mureş, Romania; 4. Clinical Hospital Mureş County, Central Laboratory, Tîrgu Mureş, România; 5. Doctoral School, University of Medicine and Pharmacy, Tîrgu Mureş, România

\section{INTRODUCTION, OBJECTIVES}

Introduction. The urinary iodine excretion (UIE) from fasting morning urine sample is a good epidemiologic indicator for iodine state, used in populational groups (schoolchildren, pregnant women) at risk to develop iodine deficiency disorders. It is not adequate to evaluate individual iodine intake. In pregnant women, especially with chronic autoimmune thyroiditis, it is important to estimate iodine state.

Objectives. To evaluate the individual iodine state in pregnant women comparing UIE from morning and 24hours urine samples.

\section{MATERIAL AND METHODS}

UIE was determined in 30 pregnant women:

24-hours UIE expressed in $\mu \mathrm{g} / \mathrm{L}$ and $\mu \mathrm{g} / \mathrm{g}$-creatinine, and these values were compared to each other.

Morning UIE was additionally assessed in 19 women, and compared to the 24-hours UIE levels

Normal UIE: $100-300 \mathrm{mcg} / \mathrm{L}$

Normal urine creatinine: $0.8-1.8 \mathrm{~g} / 24 \mathrm{~h}$
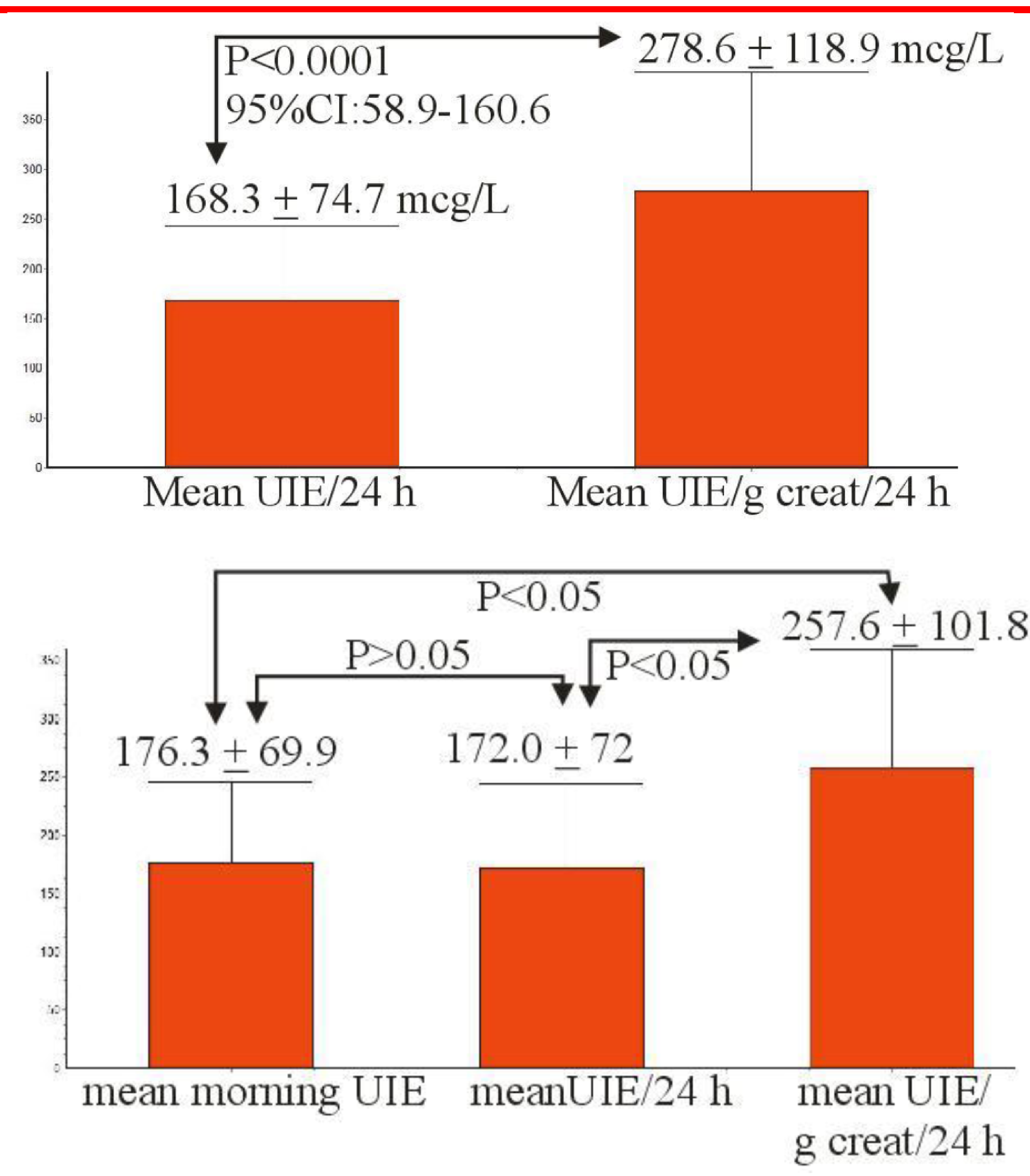

\section{RESULTS}

The mean 24-hours UIE was $168.3 \pm 74.7 \mathrm{mcg} / \mathrm{L}$, with $40 \%$ lower than 278.6 $\pm 118.9 \mathrm{mcg} / \mathrm{g}$-creatinine $(p=0.0001$, 95\%CI $=58.96-160.64)$. The individual values expressed in $\mathrm{mcg} / \mathrm{L}$ and $\mu \mathrm{g} / \mathrm{g}$-creatinine were in concordance in most of the cases $(80 \%)$, both being normal or both being reduced.

In six women $(\mathbf{2 0} \%)$ the 24 -hours UIE in $\mathrm{mcg} / \mathrm{L}$ suggested iodine deficiency, while the values in $\mathrm{mcg} / \mathrm{g}$-creatinine indicated normal iodine intake.

In the 19 pregnant women the mean morning UIE was $\mathbf{1 7 6 . 3 6} \pm \mathbf{7 5 . 8 7} \mathbf{~ m c g} / \mathrm{L}$, similar with the 24-hours UIE $\mathrm{mcg} / \mathrm{L}$, but with $30.4 \%$ lower than the 24-hours UIE $\mathrm{mcg} / \mathrm{g}$-creatinine $(257.6 \pm 101.8)$. In 16 cases $(84.2 \%)$ all the three UIE values (morning UIE, 24-hours UIE $\mathrm{mcg} / \mathrm{L}$, 24-hours UIE $\mathrm{mcg} / \mathrm{g}$ creatinine) indicated concordantly iodine deficiency or normal iodine intake, in the other three $(15.8 \%)$ the different UIE suggested different iodine state.

\section{CONCLUSIONS}

Important differences were observed between the morning UIE, 24-hours UIE in $\mu \mathrm{g} / \mathrm{L}$, 24-hours UIE in $\mu \mathrm{g} / \mathrm{g}$-creatinine, however the interpretation of these were mostly in concordance $(80 \%)$. In $20 \%$ the results could not clearly show iodine state.

Project no. 34/2013 financially supported by the internal research grants from the University of Medicine and Pharmacy Tirgu-Mures, Romania.

\section{References}

Bourdoux P. Evaluation of the iodine intake: problems of the iodine/creatinine ratio- comparison with iodine excretion and daily fluctuations of iodine concentration. Exp Clin Endocrinol Diabetes.1998;106(Suppl 3):S17-

Furnee CA et al. A critical appraisal of goiter assessment and the ratio of urinary iodine to creatinine for evaluating iodine status. Am J Clin Nutr. 1994;59(6):1415-7.

Andersen S, Pedersen KM, Pedersen IB, Laurberg P.

Variations in urinary iodine excretion and thyroid function. A

1 -year study in healthy men. Eur $\mathrm{J}$

Endocrinol. 2001;144(5):461-5. 